\title{
Sistem E-Perizinan Pada Dinas Penanaman Modal Dan Pelayanan Terpadu Satu Pintu Kabupaten Polewali Mandar
}

\author{
A. Akhmad Qashlim ${ }^{1,{ }^{*}}$, Nurfani Rahmat ${ }^{1}$, Muhammad Sarjan ${ }^{2}$ \\ ${ }^{1}$ Sistem Informasi; Univesitas Al Asyariah Mandar; Jl. Budi Utomo No. 2 Manding, Kabupaten \\ Polewali Mandar Provinsi Sulawesi Barat, telp/faks: 0428-21038; e-mail: \\ medqashlim@gmail.com, nurfanirahmat99@gmail.com, muhsarjan2018@gmail.com \\ * Korespondensi: e-mail: medqashlim@gmail.com
}

Diterima: 04 September 2021; Review: 20 Oktober 2021; Disetujui: 02 Nopember 2021

Cara sitasi: Qashlim AA, Rahmat N, Sarjan M. 2021. Sistem E-Perizinan Pada Dinas Penanaman Modal Dan Pelayanan Terpadu Satu Pintu Kabupaten Polewali Mandar. Bina Insani ICT Journal. Vol. 8 (2): 146-155.

\begin{abstract}
Abstrak: Dinas Penanaman Modal dan Pelayanan Terpadu Satu Pintu (DPMPTSP) Kabupaten Polewali Mandar saat ini sudah menerapkan sistem secara online dalam pengurusan izin, akan tetapi sistem yang dibangun masih membuat masyarakat yang mengurus surat izin bolak balik ke kantor. Undang-Undang No.25 Tahun 2009 mengatur tentang pelayanan publik untuk memberikan kejelasan salah satunya prosedurnya yang berbelit-belit dalam mengurus suatu perizinan. Oleh karena itu dibuat sistem electronik perizinan yang dapat memberikan pelayanan yang mudah dan murah agar dapat membantu masyarakat dalam hal pelayanan dengan menggunakan software JavaScript sebagai webserver, NoSQL sebagai database server,visual studio code sebagai authoring tools, phyton 3.7, at command, dan gammu sebagai SMS Gateway. Untuk pengurusan surat izin dapat dilakukan pada alamat web server https://dpmptsp-polman.web.app/. Pada sistem ini ada 3 surat izin yang menjadi sampel penelitian yaitu Surat Izin Penelitian (SIP), Surat Izin Mendirikan Bangunan (IMB) \& Surat Izin Usaha Perdagangan (SIUP). Penelitian tersebut dilakukan pada kantor Dinas Penanaman Modal \& Pelayanan Terpadu Satu Pintu Kab. Polewali Mandar (DPMPTSP). Metode penelitian yang dipakai adalah metode penelitian kualitatif, dengan menggunakan teknik mengumpulkan data melalui observasi, dokumentasi \& wawancara baik dalam lingkup kantor ataupun dalam lingkup sistem yang ada. Hasil dari penelitian yang dilaksanakan membuat masyarakat yang mengurus perizinan tidak lagi bolak-balik kantor karena sistem yang dirancang dapat memberikan notifikasi melalui SMS Gateway dengan implementasi python mengirimkan at command melalui gammu sehingga sistem membaca kode pemograman dan mengirimkan pesan informasi kepada pemohon bahwa surat yang telah diajukan sudah mendapat izin dari kepala dinas dan dapat langsung diambil pada sistem ini.
\end{abstract}

Kata kunci: DPMPTSP, pelayanan publik, perizinan, SMS Gateway

Abstract: Investment Bureau and one-stop integrated service (DPMPTSP) of Polewali Mandar Regency has currently implemented an online system in obtaining permits, but the system that was built still makes people who take care of permits go back and forth to the office. Law No. 25 of 2009 regulates public services to provide clarity, one of which is the convoluted procedure in managing a permit. Therefore, an electronic licensing system was created that can provide easy and inexpensive services in order to help the community in terms of service by using JavaScript software as a webserver, NoSQL as a database server, visual studio code as authoring tools, python 3.7, at command, and gammu as SMS Gateway. For processing a license, it can be done at the web server address https://dpmptsp-polman.web.app/. In this system, there are 3 permits that became the research sample, namely Research Permits (SIP), Building 
Construction Permits (IMB) and Trading Business Permits (SIUP). The study was conducted at the Polwarimander Regency (DPMPTSP) office, an investment and one-stop service office. The survey method used is a qualitative survey method that uses interview, documented, and observational data collection techniques, both within the office and within the existing system. Results of the survey conducted made people who take care of permits no longer go back and forth in the office because the system designed can provide notifications via SMS Gateway with the implementation of python sending at commands via Gammu so that the system reads the programming code and sends information messages to the applicant that the letter has been submitted. has received permission from the head of service and can be directly taken on this system.

\section{Keywords: DPMPTSP, public service, licensing, SMS Gateway}

\section{Pendahuluan}

Pelayanan publik dari waktu ke waktu terus mengalami perkembangan walaupun belum begitu memuaskan [1]. Pelayanan publik menjadi isu sentral dimana keadaan masyarakat semakin cerdas dan kebutuhan sehari-hari masyarakat sering meningkat untuk menuntut pelayanan yang berkualitas, mudah dan murah serta dapat dipahami oleh masyarakat. Pelayanan berkualitas adalah suatu Kebutuhan dasar untuk meningkatkan kesejahteraan masyarakat [2].

Sebagai pelindung hukum didalam pelaksanaan ranah pelayanan publik pemerintah pengeluaran Undang-Undang No. 25 Tahun 2009 mengenai pelayanan publik agar memberikan kejelasan juga pengaturan mengenai pelayanan masyarakat, idealnya memudahkan masyarakat dalam pelaksanaannya. Namun banyak masyarakat yang masih mengeluh dengan kondisi pelayanan publik saat ini. Pelayanan perizinan masih dinilai masyarakat terlalu rumit dalam pengajuan izin, karena banyaknya prosedur yang harus dilalui sehingga memerlukan waktu yang lama. Prosedur perizinan yang sederhana akan membantu minat masyarakat untuk mengajukan izin usaha. Hal itu dapat dilakukan dengan penyederhanaan pelayanan perizinan. Sistem elektronik dengan basis teknologi informasi bisa dimanfaatkan didalam pelayanan perizinan [3].

Dinas Penanaman Modal \& Pelayanan Terpadu Satu Pintu (DPMPTSP) Kab. Polewali Mandar perlu memprioritaskan penyelenggara administrasi publik dan pola perizinan yang lebih mudah bagi masyarakat guna meningkatkan kinerja perizinan juga untuk dapat memberikan kepuasan bagi masyarakat [4].

Dinas Penanaman Modal \& Pelayanan Terpadu Satu Pintu (DPMPTSP) Kab. Polewali Mandar telah menerapkan pelayanan dalam sistem online akan tetapi sistem yang ada saat ini belum dilaksanakan secara maksimal dan masih membuat masyarakat bolak balik ke kantor untuk mengumpulkan berkas dan mengambil surat izin. Pelayanan yang diterapkan saat ini sudah menggunakan website dengan mendownload formulir permohonan izin lalu diprint dan pemohon melengkapi persyaratan permohonan izin lalu mengumpulkan berkas dan formulir izin ke kantor setelah itu pihak kantor akan memberitahukan kepada pemohon untuk menunggu beberapa hari sampai surat izin yang diurus diterbitkan oleh kantor. Setelah surat terbit pihak kantor akan menghubungi pemohon agar kembali ke kantor untuk mengambil surat izin pemohon yang telah diterbitkan. Pegawai kantor juga sering kali dimintai kembali berkas yang telah mendapatkan izin untuk diarsipkan akan tetapi pegawai kantor kewalahan dalam mencari kembali berkas pemohon diakibatkan penumpukan berkas pemohon yang telah mengurus perizinan [5].

Sistem E-Perizinan yang dirancang ini juga menggunakan website dengan penerapan SMS gateway, sistem ini dibuat agar dapat membantu masyarakat atau pemohon untuk mengisi formulir permohonan izin dan melengkapi berkas persyaratan izin langsung melalui sistem ini sehingga pemohon tidak lagi mondar mandir mendatangi kantor. Sistem ini dibuat sesederhana mungkin dari sistem sebelumnya agar pemohon dapat dengan mudah mengerti dan tidak menyulitkan pemohon dalam menggunakan sistem ini.

Sistem E-Perizinan ini dibangun menggunakan JavaScript sebagai web server dimana Javascript dapat berfungsi sebagai program aplikasi yang memproses masukan yang diberikan user dan memberikan hasil sesuai dengan diprogramkan. Untuk database pada sistem ini menggunakan NoSQL, Untuk membantu mengatasi masalah ini, sistem database NoSQL telah muncul. Sistem ini telah diatur ke dalam empat kategori, dokumen database, database kolom, 
penyimpanan nilai kunci, dan database grafik. Ada juga kategori hybrid yang mencampur beberapa model data yang dikenal memiliki database multi-model. Dalam sistem ini mempelajari bagaimana konsistensi diterapkan pada berbagai non-cloud database NoSQL. Perancang sistem basis data ini telah merancang strategi yang berbeda untuk menangani konsistensi, sehingga mengasumsikan pertukaran variabel antara konsistensi dan atribut kualitas lainnya, seperti: ketersediaan, latensi, dan toleransi partisi jaringan [6].

Sistem ini diterapkan menggunakan SMS Gateway sebagai penyampaian informasi karena saat ini penyebaran informasi tercepat salah satunya melalui handphone. App mobile juga sangat canggih dalam penggunaannya akan tetapi untuk menerapkan app mobile dalam sistem ini menurut penulis akan membuat masyarakat ribet dalam penggunaannya karena perlu untuk mendownload aplikasi, adapun mendownload aplikasi membuat penyimpanan pada handphone bertambah sehingga pemohon akan menghapus beberapa file jika memori penyimpanan penuh.

Untuk SMS Gateway pada sistem ini dibuat menggunakan bahasa pemograman python, at command, dan gammu. Pyton mengirimkan at command melalui gammu agar perintah yang dikirimkan python berupa pengiriman pesan dari gammu menuju nomor ponsel pemohon. Sehingga pemohon menerima pesan hasil dari berkas yang dikirimkan kepada pihak admin sistem [8]. Visual Studio Code salah satu aplikasi pemograman yang dipakai untuk menuliskan kode-kode program dalam sistem ini, visual studio code adalah perangkat lunak yang menyorotkan pada sintaksis pemograman yang umum dan lengkap sehingga aplikasi ini dapat memudahkan untuk pembuatan program-program dalam menuliskan sintaks.

SMS Gateway merupakan Sebuah sistem yang menghubungkan ponsel, server, dan SMS sebagai informasi. SMS adalah teknologi yang menyediakan layanan antara ponsel dan mengirim dan menerima pesan. Teknologi SMS dapat membawa data terbatas Hal ini menunjukkan bahwa SMS Gateway akan membantu masyarakat (pemohon) mendapatkan informasi tentang surat izin yang diajukan apakah pengajuan surat izin diterima ataupun ditolak oleh kantor. Sistem kerja SMS Gateway pada sistem ini sistem mengirimkan pesan kepada pemohon yang berisi informasi dari berkas yang dikirim pemohon melalui modem dan jaringan GSM [7].

Penelitian ini bertujuan untuk mengetahui dan merancang sistem pelayanan perizinan sesuai dengan permasalahan yang ada pada DMPTSP kabupaten Polewali Mandar guna untuk dapat memberikan kontribusi terhadap perkembangan yang bersifat teori maupun praktek pelayanan publik bagi DPMPTSP kabupaten Polewali Mandar.

\section{Metode Penelitian}

Metode penelitian kualitatif dalam penelitian ini digunakan sebagai kegiatan ilmiah yang dilakukan dengan tahapan-tahapan dimulai dari menentukan topik, observasi, dengan mengumpulkan data dan menganalisis data, serta wawancara dengan staf kantor, sehingga diperoleh pemahaman tentang topik, gejala atau masalah tertentu. Dikatakan bertahap karena kegiatan ini berlangsung mengikut suatu proses tertentu, sehingga ada tahapan yang perlu dilalui secara bertahap sebelum melanjutkan ke tahap berikutnya [9]. Ciri-ciri metode kualitatif meliputi: 1) Sumber data berada pada situasi yang tidak wajar (natural setting), tidak dimanipulasi oleh kuesioner dan tidak dijadikan sebagai kelompok eksperimen, 2) Laporannya sangat deskriptif, 3) Memprioritaskan produk dan proses, 4) Instrumen penelitian sebagai peneliti (key instrument), 5) Mencari makna, dilihat dari pikiran juga perasaan informan [10].

Alat pengumpulan data atau instrumen penelitian dalam metode kualitatif yaitu si peneliti sendiri. Jadi, Peneliti merupakan alat yang penting, sehingga pada saat mengumpulkan data, peneliti harus aktif terjun langsung ke lapangan. Observasi partisipan, wawancara, dan dokumentasi merupakan teknik pengumpulan data yang sering digunakan [10].

Tujuan penelitian kualitatif tergantung pada tujuannya. Ada beberapa jenis penelitian kualitatif yang berkaitan dengan tujuan tersebut. Artinya, penelitian dilakukan untuk kepentingan penelitian itu sendiri, untuk keperluan evaluasi, untuk menyelesaikan disertasi atau untuk kepentingan pribadi. Kriteria penilaiannya berbeda maka dari itu tujuannya pun berbeda [9].

Di beberapa daerah, hakikat Isu yang diselidiki lebih tepat bila diselidiki dengan pendekatan atau metode kualitatif. Misalnya, Anda ingin menjelaskan bagaimana orang mengalami rasa sakit, kecanduan narkoba, depresi, peningkatan antusiasme untuk belajar, peningkatan minat, sikap positif, dan motivasi untuk sesuatu. Dalam kasus seperti itu, metode kualitatif dapat mengungkapkan dan memahami sesuatu di balik fenomena yang sebelumnya 
tidak di ketahui. Metode kualitatif ini juga dapat memberikan rincian yang kompleks tentang fenomena yang sulit dipahami dan diungkapkan dengan metode kuantitatif [11].

\section{Bahan Penelitian}

Bahan penelitian salah satu hal yang paling penting dalam menentukan arah program aplikasi. Bahan penelitian yang dibutuhkan dalam penelitian ini yaitu formulir surat izin dan surat izin yang telah ditanda tangani kepala dinas DPMPTSP Kabupaten Polewali Mandar serta hasil dari wawancara staf kantor [3].

\section{Pengumpulan Data}

Data yang dibutuhkan meliputi data primer dan sekunder. Data primer adalah data yang di peroleh dari sumber data lansung pada subyek peneliti mengenai sikap dan perilaku serta pelayanan perijinan pada masyarakat juga juga bahan primer didapatkan daripada peraturan perundang-undang yang berkaitan dengan pokok pembahasan yang nantinya diteliti yaitu UU No. 25 Tahun 2009 tentang pelayanan publik. Sedangkan sumber data sekunder merupakan data yang berasal dari bahan pustaka yang digunakan agar membantu dan memahami berbagai konsep hukum didalam hukum primer, baik dari jurnal, makalah, buku maupun dari karya ilmiah lainnya tentang perizinan DPMTSP dan penerapan pelayanan publik pada masyarakat [12].

Ada tiga tahapan kegiatan pengumpulan data yang harus dilalui, antara lain Datang ke lokasi penyidikan dan mengamati, mengamati langsung permasalahan apa saja yang ditemukan pada target penyidikan kantor DMPTPTSP, melakukan wawancara yaitu prosedur dan sistem yang sedang diterapkan di kantor DMPTPTSP, investigasi, dan literatur. teori dalam penelitian sebagai poin tambahan untuk meninjau survei [13].

\section{Flowchart Penelitian}

Sebelum melakukan penelitian ini, peneliti sebaiknya mempertimbangkan data sekunder yaitu data dari jurnal ilmiah yang bersumber dari berbagai jurnal yang terkait dengan penelitian ini, jurnal nasional dan internasional, buku, dan publikasi usia 5 tahun ke bawah. Internet. Tahun. Sumber data sekunder yang dihasilkan adalah literatur yang masih relevan dengan penelitian ini. Penelitian-penelitian sebelumnya direview dalam bentuk jurnal review untuk membantu menemukan persamaan topik, teori, dan perbedaan, dan hasil penelitian sebelumnya direview sebagai bahan pembelajaran saat melakukan penelitian ini. Selain itu peneliti melakukan observasi lapangan yaitu secara langsung mendatangi kantor tersebut untuk melihat sendiri permasalahan apa saja yang ditemukan pada Kantor Penanaman Modal \& Kantor Pelayanan Terpadu Satu Pintu Kab. Polewali Mandar.

Dalam perencanaan perangkat lunak, yang pertama dilakukan identifikasi masalah. Dalam proses ini peneliti mengidentifikasi setiap permasalahan yang terjadi pada sistem pelayanan perijinan yang sedang dilaksanakan, kemudian dijelaskan mengenai latar belakang permasalahan tersebut. Setelah mengidentifikasi masalah, langkah selanjutnya ialah mengumpulkan data. Pengumpulan data dilakukan dengan cara studi literatur dari penelitian sebelumnya dan mulai melakukan wawancara dan dokumentasi kepada karyawan dan staf kantor untuk mengumpulkan data dan dokumentasi mengenai penelitian tersebut. Terakhir, sebagai langkah persiapan dalam perencanaan, perlu dilakukan analisis perangkat keras dan perangkat lunak. Perancangan aplikasi ini menggunakan pemrograman JavaScript menggunakan database Nosql. Perangkat lunak yang digunakan adalah Visual Studio Code dan Python untuk implementasi SMS Gateway.

Pada tahap perancangan sistem ini peneliti membagi menjadi 3 tahapan. Tahapan pertama, pembuatan rancangan basis data yang berisi data pemohon yang akan dimasukkan ke dalam sistem yang akan di bangun, diagram yang akan ditampilkan pada halaman awal untuk melihat izin-izin yang telah dikeluarkan oleh kantor melalui sistem yang telah dibuat. Tahapan kedua membuat rancangan User Interface, yaitu tampilan antar muka yang akan menjadi visualisasi dari rancangan sistem yang dibuat oleh peneliti. Tahapan ketiga adalah coding atau menerjemahkan desain yang telah dibuat ke dalam perangkat lunak dengan menggunakan bahasa pemrograman. Dalam perancangan aplikasi sistem e-perizinan ini, pengujian sistem menggunakan metode Blackbox Testing, Whitebox Testing, dan Lab. Riset. Pengujian yang bertujuan untuk mengetahui terjadinya kesalahan atau kesalahan fungsi pada fitur-fitur pada aplikasi. Pengujian dilakukan dengan cara mengecek setiap tools aplikasi 
dengan perlakuan benar dan salah untuk menguji fungsionalitas aplikasi oleh peneliti. Pengujian ini melibatkan 2 jenis responden yaitu responden dari admin dan pengguna yang terdiri dari 3 orang. Setelah itu, kuesioner tertutup diberikan untuk menilai aplikasi dengan parameter tertentu.

Dibawah ini adalah flowchart diagram penelitian yang akan menjelaskan alur penelitian.
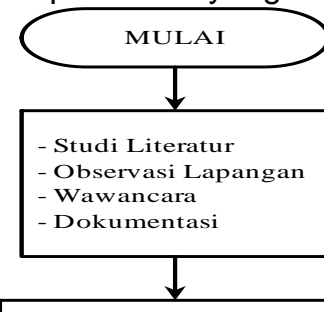

Perencanaan Software - Identifikasi Masalah Pengumpulan Data - Analisa Kebutuhan
Software dan Hardware

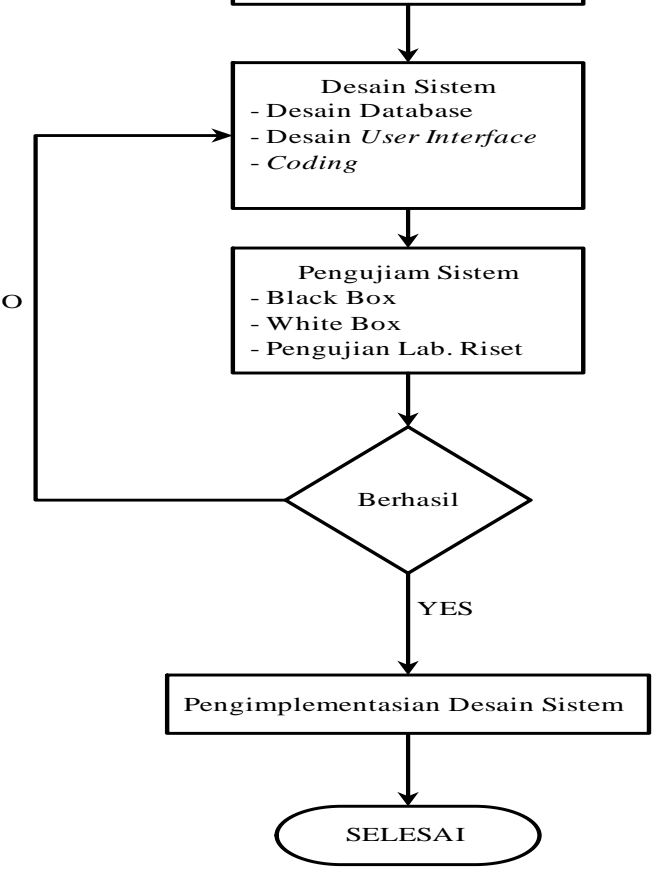

Sumber: Hasil Penelitian (2021)

Gambar 1. Flowchart Penelitian

\section{Hasil dan Pembahasan}

Hasil penelitian ini sebuah aplikasi Sistem E-Perizinan Pada Dinas Penanaman Modal \& Pelayanan Terpadu Satu Pintu (DPMPTSP) Kab. Polewali Mandar menggunakan bahasa pemograman JavaScript sebagai web server, NoSQL sebagai database server, dan python digunakan sebagai notifikasi SMS gateway dan visual studio code sebagai web authoring tools.

Pada aplikasi ini mempunyai dua level login system satu untuk admin dan satu untuk user (pengguna). Login system admin dipegang oleh pihak kantor Dinas Penanaman Modal \& Pelayanan Terpadu Satu Pintu (DPMPTSP) Kab. Polewali Mandar yang dimana form admin mempunyai beberapa fitur yang pertama yaitu fitur dasboard yang menampilkan jumlah pengajuan masing-masing surat izin yang telah didaftar oleh pemohon baik yang diterima maupun yang diltolak dan laporan hasil penerima izin yang dapat di print langsung untuk kebutuhan kantor. Selanjutnya ada fitur izin penelitian, izin mendirikan bangunan, dan izin usaha perdagangan masing-masing fitur menampilkan biodata dan berkas yang telah di lengkapi pemohon untuk mendapatkan surat izin resmi yang ditanda tangani langsung oleh kepala DPMPTSP. Ketika biodata dan berkas telah dilengkapi pemohon dengan benar maka pihak admin akan mencetak berkas dan biodata pemohon untuk dikirimkan pada kantor Kesatuan Bangsa dan Politik (KESBANGPOL) Kabupaten Polewali pada permohonan surat izin 
penelitian, kantor Dinas Pekerjaan Umum (PU) pada permohonan surat izin mendirikan bangunan, dan kantor dinas Perindustrian dan Perdagangan (DISPERINDAG) kabupaten Polewali Mandar pada surat izin usaha perdagangan untuk dibuatkan surat rekomendasi pada masing-masing bidang perizinan dan kantor tujuan rekomendasi. Setelah surat rekomendasi sudah dikirimkan kembali pada DPMPTSP Kabupaten Polewali Mandar, maka pihak admin dari sistem e-perizinan ini akan memberikan persetujuan dalam bentuk surat resmi yang ditanda tangani oleh kepala dinas dan pemohon akan mendapatkan notifikasi SMS gateway berupa pesan dan informasi bahwa pengajuan surat telah diterima dan surat sudah dapat diambil melalui sitem ini.Sistem SMS Gateway dapat membantu pemohon mendapatkan informasi dari berkas yang diajukan tanpa harus ke kantor lagi.

Login system user (pemohon) digunakan oleh masyarakat yang ingin melakukan pengajuan surat izin, terlebih dahulu harus melalukan registrasi akun untuk dapat mengajukan surat. Setelah melakukan registrasi akun pemohon dapat masuk pada login/masuk dengan memasukkan username dan password yang telah diregist sebelumnya. Dalam sistem terdapat empat fitur yang pertama ada fitur dasboard menampilkan jumlah pengajuan surat masingmasing izin. Selanjutnya fitur berkas saya menampilkan upload berkas baik dalam bentuk file document maupun picture, di fitur ini resolusi berkas yang diupload tidak membatasi ukuran berkas jadi pemohon bebas mengupload berkas tanpa mengubah ukuran resolusinya. Fitur selanjutnya ada fitur pengajuan surat baru yang didalamnya terdapat pilihan surat yang ingin diajukan. Tiap surat yang ingin diajukan menampilkan persyaratan yang harus dilengkapi dalam pengajuan surat yang terletak dibagian atas. Setelah melengkapi berkas pemohon sudah dapat mengisi form data yang ada, lalu mengirimkan form dan berkas yang telah dilengkapi. Jika berkas yang dikirim pada sistem ini tidak sesuai maka admin akan mengirimkan pesan SMS gateway berupa penolakan disertai dengan alasan penolakan.

Tabel 1. Perbandingan Sistem yang sedang Berjalan dan Sistem yang Dirancang

\begin{tabular}{llll}
\hline No & \multicolumn{1}{c}{ Alur } & \multicolumn{1}{c}{ Sistem yang Sedang Berjalan } & \multicolumn{1}{c}{ Sistem yang Dirancang } \\
\hline 1 & $\begin{array}{l}\text { Formulir } \\
\text { Perizinan }\end{array}$ & $\begin{array}{l}\text { Dow nload formulir perizinan mengisi manual } \\
\text { formulir }\end{array}$ & $\begin{array}{l}\text { Mengisi formulir perizinan melalui form pada } \\
\text { sistem }\end{array}$ \\
\hline 2 & $\begin{array}{l}\text { Berkas } \\
\text { Persyaratan }\end{array}$ & Print dan fotocopyberkas persyaratan & Upload berkas persyaratan \\
\hline 3 & Berkas salah & $\begin{array}{l}\text { Dihubungi langsung oleh kantor jika berkas } \\
\text { yang dilengkapi kurang dan kembali kekantor } \\
\text { untuk melengkapi berkas }\end{array}$ & $\begin{array}{l}\text { admin sistem memberikan informasi melalui } \\
\text { sms jika berkas persyaratan tidak lengkap } \\
\text { dan dapat masuk ke sistem kembali untuk } \\
\text { melengkapi berkas }\end{array}$ \\
\hline 4 & Suratizin & $\begin{array}{l}\text { Surat izin yang telah terbit akan diberikan } \\
\text { langsung pada pemohon dan pemohon akan } \\
\text { disuruh kembali ke kantor untuk mengambil } \\
\text { surat izin. }\end{array}$ & $\begin{array}{l}\text { surat izin yang telah terbit maka pemohon } \\
\text { akan dapatkan notifikasi melalui SMS } \\
\text { dan dapan mengambil surat izin langsung } \\
\text { pada sistem ini }\end{array}$ \\
\hline
\end{tabular}

Sumber: Hasil Penelitian (2021)

\section{User Interface Program}

$\mathrm{UI}$ atau yang biasa disebut user interface adalah jenis presentasi grafis yang langsung diidentikkan dengan (client), UI berfungsi untuk antar muka atau menguraikan data antara klien dan kerangka kerja dengan tujuan agar PC dapat dimanfaatkan. Alasan dibuatnya program ini untuk mengatur ulang dan mempercepat aktifitas dan untuk membingkai kerangka kerja yang unggul.

Gambar 3. Menampilkan button registrasi akun yang jika diklik akan menampilkan form pengisian identitas yang wajib diisi jika ingin mengurus pengajuan surat izin apabila pemohon belum mempunyai akun. Jika pemohon sudah melakukan registrasi sebelumnya dan sudah mempunyai akun maka pemohon dapat masuk pada button login/masuk. Ditampilan ini juga memperlihatkan daftar penerima surat izin resmi dan menampilkan grafik penerima. Menampilkan daftar penerima izin resmi sesuai tanggal keluarnya surat beserta deskripsi izin yang diajukan dan disetujui. Di halaman ini juga dapat memperlihatkan halaman dashboard. Dasboard adalah bidang konfigurasi data yang telah lama digunakan untuk menyampaikan pengukuran bisnis yang signifikan.Teknik ini menggunakan antar muka terbaik untuk korespondensi visual [14]. Dasboard menampilkan jumlah data pengajuan surat yang telah diajukan oleh pemohon baik yang diterima maupun yang ditolak diantaranya surat izin penelitian (SIP), surat izin mendirikan bangunan (IMB), dan surat izin usaha perdagangan (SIUP). 


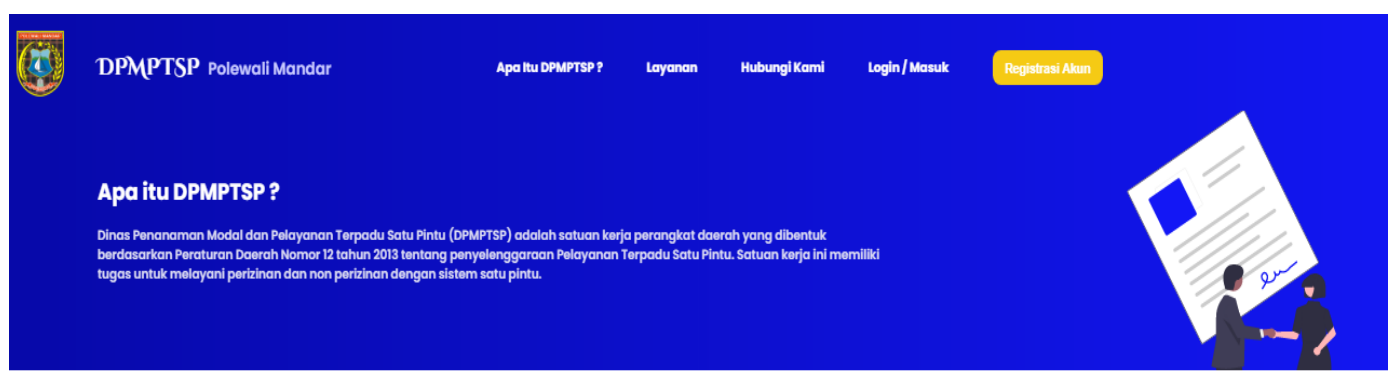

Layanan/ Service

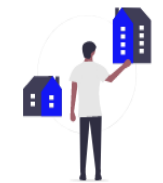

Izin Mendirikan Bangunan (IMB)

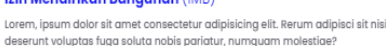

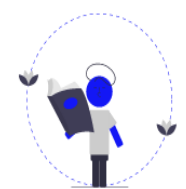

Surat zin Penelitian (SIP)

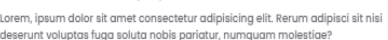

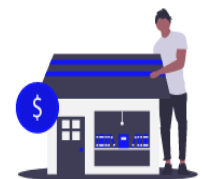

Surat Izin Usaha Perdagangan (SIUP)

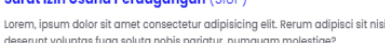

Sumber: Hasil Penelitian (2021)

Gambar 2. Tampilan Awal Sistem E-Perizinan

SMS merupakan teknologi yang menyediakan layanan untuk mengirim dan menerima pesan antar ponsel dalam jaringan GSM, CDMA dan TDMA. 2) Satu SMS hanya bisa menampung data maksimal 140 byte, yaitu satu SMS bisa menampung sebanyak 160 karakter latin atau 70 karakter nonlatin. Teks SMS mendukung bahasa di hampir semua negara, termasuk Korea, Arab, China, dan Jepang. 3) SMS gateway yaitu sebuah sistem yang berperan sebagai perantara antara telepon genggam dengan sistem yang berfungsi sebagai server yang memiliki SMS sebagai informasi 4) SMS gateway memerlukan komponen alat penunjang untuk menjalankan aplikasi yaitu komponen PC, aplikasi seluler dan pendukung [8]. Pada gambar 14 SMS Gateway menampilkan pesan yang dikirimkan sistem pada pemohon berupa penerimaan berkas dan penolakan pengajuan apabila terdapat kesalahan yang dilakukan pemohon baik pada berkas lampiran maupun pada form pengisian data.
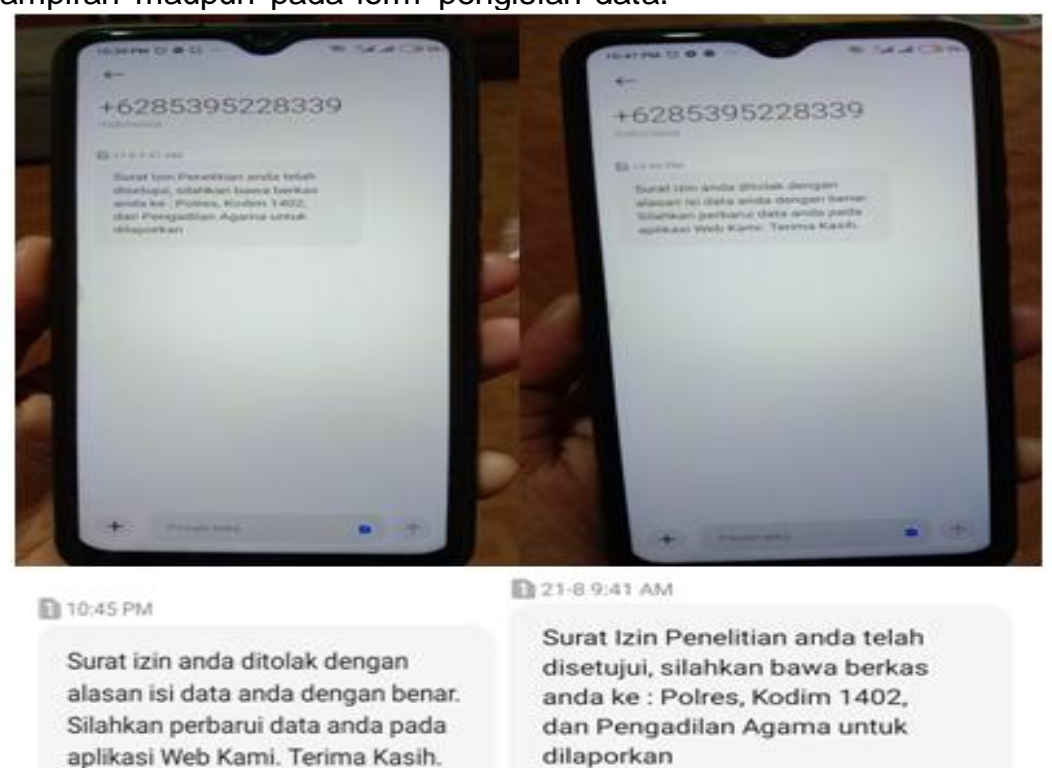

$$
\begin{aligned}
& \text { Surat Izin Penelitian anda telah } \\
& \text { disetujui, silahkan bawa berkas } \\
& \text { anda ke: Polres, Kodim } 1402 \text {, } \\
& \text { dan Pengadilan Agama untuk } \\
& \text { dilaporkan }
\end{aligned}
$$

Sumber: Hasil Penelitian (2021)

\section{Gambar 3. SMS Gateway}

\section{Visualisasi Proses Alur Data Pada Sistem E-Perizinan}

Visualisasi proses alur data pada sistem E-Perizinan dijelaskan pada gambar 4. 


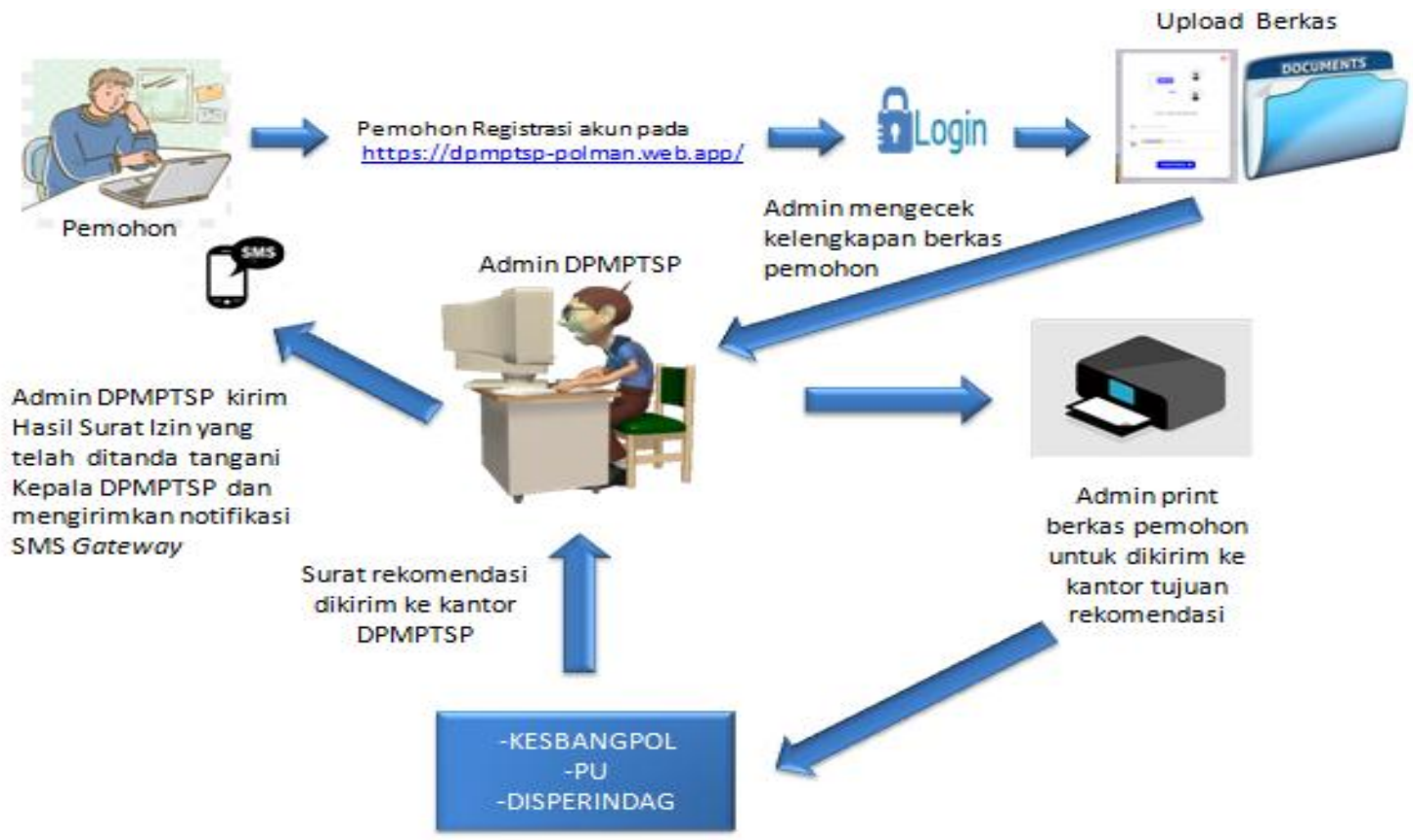

Sumber: Hasil Penelitian (2021)

Gambar 4. Visualisasi Proses Alur Data Sistem E-Perizinan

\section{Pengujian}

Sebelum menerapkan sebuah aplikasi atau program di instansi, pengujian dilakukan terlebih dahulu untuk mengetahui kesalahan (error) pada program yang akan dilaksanakan [14]. Metode pengujian sistem yang digunakan oleh penulis adalah metode pengujian black box, white box dan pengujian laboratorium riset pada Universitas Al Asyariah mandar. Metode pengujian blackbox \& whitebox dilakukan dengan melihat hasil eksekusi melalui data uji juga pengecekan fungsionalitas software. Metode pengujian laboratorium riset dilakukan pada laboratorium Universitas Al Asyariah Mandar dengan melakukan pengecekan system baik secara online maupun offline untuk melihat fungsi dari masing-masing fitur apakah berjalan sesuai yang diinginkan dan melihat perbedaan system antara online dan offline. Pengujian metode black box admin dijelaskan pada tabel 2 .

Tabel 2. Pengujian Metode Black Box Admin

\begin{tabular}{|c|c|c|c|c|}
\hline No & Pengujian & Hasil yang diharapkan & $\begin{array}{l}\text { Hasil } \\
\text { Pengujian }\end{array}$ & Ket \\
\hline 1. & $\begin{array}{l}\text { Form login admin } \\
\text { button submit }\end{array}$ & $\begin{array}{l}\text { Ketika diklik, sistem akan memeriksa nama pengguna } \\
\text { dan kata sandi Anda. Jika cocok, tampilan pertama } \\
\text { formulir manajemen akan tampil, dan jika tidak cocok } \\
\text { atau tidak valid maka textbox username dan password } \\
\text { akan kosong dan login tidak berhasil. }\end{array}$ & $\begin{array}{l}\text { Sesuai yang } \\
\text { diharapkan }\end{array}$ & Ok \\
\hline 2. & $\begin{array}{l}\text { Form login admin } \\
\text { menu utama }\end{array}$ & $\begin{array}{l}\text { Jika username dan passw ord sudah cocok atau valid } \\
\text { maka akan langsung menuju ke menu utama } \\
\text { menampilkan dashboard, izin penelitian, izin mendirikan } \\
\text { bangunan, dan izin usaha persadangan serta button } \\
\text { logout. }\end{array}$ & $\begin{array}{l}\text { Sesuai yang } \\
\text { diharapkan }\end{array}$ & Ok \\
\hline 3 & $\begin{array}{l}\text { Form login admin } \\
\text { menu dasboard }\end{array}$ & $\begin{array}{l}\text { Jikaa menu dashboard diklik maka yang akan tampil yaitu } \\
\text { jumlah surat yang telah masuk pada sistem. }\end{array}$ & $\begin{array}{l}\text { Sesuai yang di } \\
\text { harapkan }\end{array}$ & Ok \\
\hline 4 & $\begin{array}{l}\text { Form login admin } \\
\text { menu surat izin } \\
\text { penelitian (SIP), } \\
\text { Surat } \\
\text { mendirikan izin } \\
\text { bangunan (IMB), } \\
\begin{array}{l}\text { surat izin usaha } \\
\text { perdagangan }\end{array}\end{array}$ & $\begin{array}{l}\text { Jika menu izin ini diklik maka yang akan tampil daftar } \\
\text { surat yang telah diajukan oleh pemohon dan dapat dilihat } \\
\text { berkas persyaratan yang dimasukkan oleh pemohon, di } \\
\text { menu ini juga dapat menentukan apakah persyaratan dan } \\
\text { formulir yang diisi pemohon lengkap atau tidak maka } \\
\text { admin dapat menolak permohonan dan juga dengan } \\
\text { memberikan surat yang telah resmi jika telah melengkapi } \\
\text { persyaratan dan mengisi formulir dengan benar maka } \\
\text { admin akan mengirimkan notifikasi kepada kepala bidang } \\
\text { pelayanan dan kepala kantor DPMPTSP. }\end{array}$ & $\begin{array}{l}\text { Sesuai yang di } \\
\text { harapkan }\end{array}$ & Ok \\
\hline
\end{tabular}


Pengujian metode black box user dijelaskan pada tabel 3.

Tabel 3. Pengujian Metode Black Box User

\begin{tabular}{|c|c|c|c|c|}
\hline No & Pengujian & Hasil yang diharapkan & $\begin{array}{l}\text { Hasil } \\
\text { pengujian }\end{array}$ & Ket \\
\hline 1. & $\begin{array}{l}\text { Form login } \\
\text { pemohon } \\
\text { button submit }\end{array}$ & $\begin{array}{l}\text { Jika diklik maka sistem akan mengecek username dan } \\
\text { passw ord, jika cocok maka tampilan aw al form admin } \\
\text { akan tampil, dan jika tidak cocok atau tidak valid maka } \\
\text { textbox username dan password akan kosong dan } \\
\text { login tidak berhasil. }\end{array}$ & $\begin{array}{l}\text { Sesuai yang } \\
\text { diharapkan }\end{array}$ & Ok \\
\hline 2 & $\begin{array}{l}\text { Form login } \\
\text { pemohon menu } \\
\text { utama }\end{array}$ & $\begin{array}{l}\text { Jika username dan password sudah cocok atau valid } \\
\text { maka akan langsung menuju ke menu utama } \\
\text { menampilkan dashboard, berkas saya, pengajuan surat } \\
\text { baru, daftar surat saya dan juga button logout. }\end{array}$ & $\begin{array}{l}\text { Sesuai yang } \\
\text { diharapkan }\end{array}$ & Ok \\
\hline 3 & $\begin{array}{l}\text { Form login } \\
\text { pemohon menu } \\
\text { dashboard }\end{array}$ & $\begin{array}{l}\text { Jikaa menu dashboard diklik maka yang akan tampil } \\
\text { yaitu jumlah surat yang telah diajukan pemohon pada } \\
\text { sistem. }\end{array}$ & $\begin{array}{l}\text { Sesuai yang } \\
\text { diharapkan }\end{array}$ & Ok \\
\hline 4 & $\begin{array}{l}\text { Form login } \\
\text { pemohon menu } \\
\text { berkas saya }\end{array}$ & $\begin{array}{l}\text { Jika menu berkas saya diklik maka yang akan tampil } \\
\text { penambahan berkas file dan juga dapat mengedit atau } \\
\text { menghapus file yang telah diupload. }\end{array}$ & $\begin{array}{l}\text { Sesuai yang } \\
\text { diharapkan }\end{array}$ & Ok \\
\hline 5 & $\begin{array}{l}\text { Form login } \\
\text { pemohon menu } \\
\text { pengajuan berkas }\end{array}$ & $\begin{array}{l}\text { Jika menu ini diklik maka yang akan tampil pilihan surat } \\
\text { yang akan diajukan dimana masing-masing memiliki } \\
\text { persyaratan berkas yang harus dilengkapi dan } \\
\text { pengisian formulir pada form tersebut lalu mengirim } \\
\text { berkas dan formulir. }\end{array}$ & $\begin{array}{l}\text { Sesuai yang } \\
\text { diharapkan }\end{array}$ & Ok \\
\hline 6 & $\begin{array}{l}\text { Form login } \\
\text { pemohon menu } \\
\text { daftar surat saya }\end{array}$ & $\begin{array}{l}\text { Jika menu daftar surat saya diklik maka yang tampil } \\
\text { yaitu surat yang telah diajukan dimana surat yang } \\
\text { belum mendapatkan izin atau masih menunggu } \\
\text { permohonan bisa diedit kembali dan surat yang telah } \\
\text { mendapatkan konfirmasi dari SMS gateway jika surat } \\
\text { tercentang artinya surat sudah dapat izin dan sudah } \\
\text { ditanda tangani oleh kepala dinas, jika surat tanda } \\
\text { jempol baw ah artinya surat ditolakberdasarkan alas an } \\
\text { penolakan. }\end{array}$ & $\begin{array}{l}\text { Sesuai yang } \\
\text { diharapkan }\end{array}$ & Ok \\
\hline
\end{tabular}

Sumber: Hasil Penelitian (2021)

Pengujian laboratorium komputer Universitas Al Asyariah Mandar menghasilkan semua fitur berjalan dengan baik. Pada pengujian komponen sistem meliputi database system, konfigurasi menggunakan laptop, firebase, dan node JS dan untuk pengujian user interface (antarmuka) yang diuji meliputi fitur estetika, visability, dashboard, berkas saya, pengajuan surat baru, dan fitur daftar surat saya. Login sistem juga dilihat oleh penguji dan juga SMS Gateway dicek pada saat pengiriman. Hasil pengujian dapat dilihat pada gambar 5.

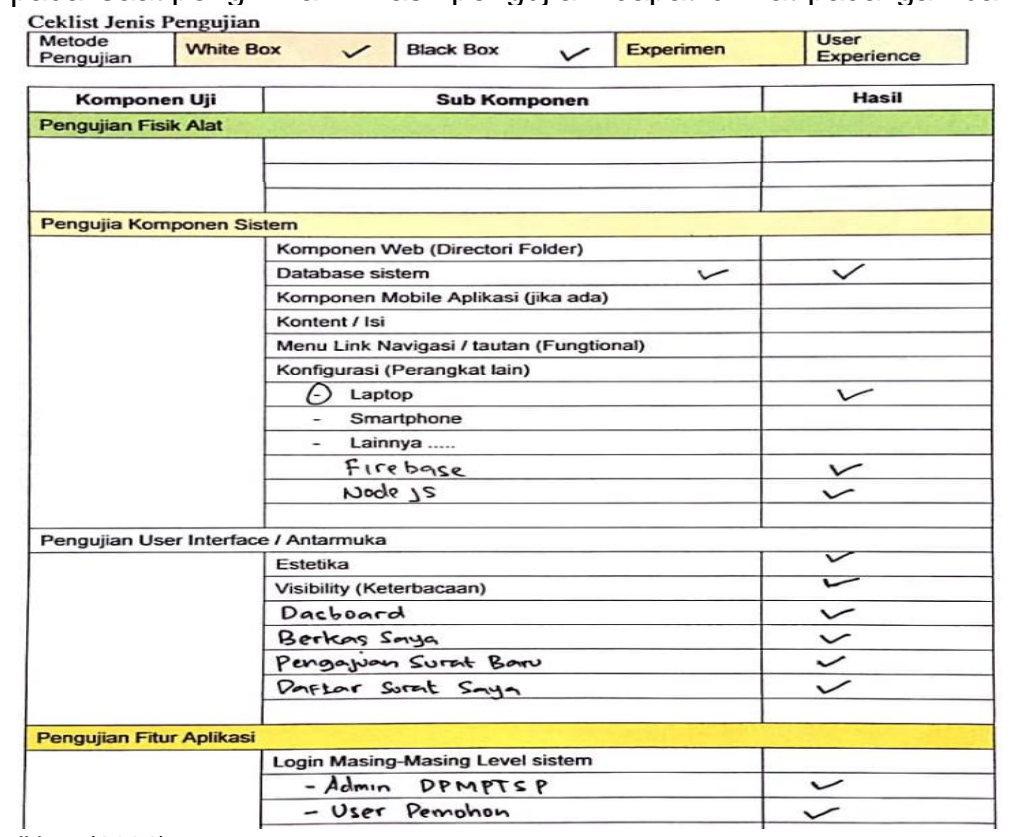

Sumber: Hasil Penelitian (2021)

Gambar 5. Pengujian Tes Riset Lab Universitas Al Asyariah Mandar 


\section{Kesimpulan}

Adapun kesimpulan terhadap penelitian yang dilakukan Sistem E-Perizinan Pada Dinas Penanaman Modal \& Pelayanan Terpadu Satu Pintu (DPMPTSP) Kab. Polewali Mandar berhasil dibangun dengan menerapkan sistem SMS Gateway dan menerapkan sistem sesuai Standard Operasional Prosedure (SOP) perizinan yang disampaikan kantor. Setelah penelitian dilakukan, penulis mengambil kesimpulan dari hasil pengujian system terhadap masyarakat dan instansi meliputi : 1) Dengan adanya sistem yang telah dirancang ini sehingga dapat memenuhi kebutuhan pengguna/ pemohon dalam mengurus surat izin dan pencatatan izin sehingga dapat mengurangi terjadinya kesalahan yang dilakukan oleh operator kantor, 2) Dengan adanya sistem ini penumpukan kertas berupa berkas-berkas persyaratan pengurusan izin pada kantor telah berkurang karena telah diarsipkan pada sistem ini. Dalam pembuatan sistem E-Perizinan ini masih banyak hal yang perlu dikembangkan dengan menambah fitur-fitur yang dibutuhkan oleh kantor pada bidang perizinan ataupun bidang non-perizinan.

\section{Ucapan Terima Kasih (Opsional)}

Peneliti mengucapkan banyak terima kasih kepada Universitas Al Asyariah Mandar yang telah memberikan pembiayaan penelitian ini dan Dinas Penanaman Modal Pelayanan Terpadu Satu Pintu Kab. Polewali Mandar yang telah mendukung selama berjalannya kegiatan penelitian di kantor tersebut.

\section{Referensi}

[1] M. P. Bilyastuti, "Pelayanan Publik Dinas Penanaman Modal Dan Pelayanan Terpadu Satu Pintu (Dpmptsp) Kabupaten Ponorogo Dengan Sijitu (Sistem Informasi Perizinan Terpadu)," Reformasi, vol. 9, no. 1, p. 82, 2019, doi: 10.33366/rfr.v9i1.1346.

[2] T. R. Susianawati, "Analisis Kesiapan Inovasi Layanan Sistem Informasi Manajemen Dan Pelayanan Perizinan Elektronik (SIMPPEL) di Dinas Penanaman Modal Pelayanan Terpadu Satu Pintu dan Tenaga Kerja Kabupaten Tuban," Jurnal Publika, vol. 6, no.5, pp. $1-7,2017$.

[3] N. Rysaka, "Penerapan Sistem Elektronik Dalam Pelayanan Perpajakan (Studi Pada Kantor Pelayanan Pajak Pratama Malang Utara)," J. Adm. Publik Mhs. Univ. Brawijaya, vol. 2, no. 3, pp. 420-425, 2014.

[4] G. R. Muafa and E. H. Fanida, "Penerapan Sistem Perizinan Online Single Submission (OSS) Di Dinas Penanaman Modal Dan Pelayanan Terpadu Satu Pintu (DPMPTSP) Kabupaten Sidoarjo," Unesa, pp. 1-7, 2019.

[5] R. Hidayat, H. Wijono, and F. Hanum, "Transparansi Informasi Pelayanan Di Dinas Penanaman Modal Dan Pelayanan Terpadu Satu Pintu (Dpmptsp) Kabupaten Situbondo," Acton, vol. 14, no. 1, pp. 1-14, 2018.

[6] M. Diogo, B. Cabral, and J. Bernardino, "Consistency Models of NoSQL Databases," pp. 1-19, 2019, doi: 10.3390/fi11020043.

[7] H. Murti and H. Listiyono, "Aplikasi SMS Gateway," Dinamik, vol. 14, no. 1, pp. 30-34, 2009.

[8] W. Bagye, M. Salehudin, and K. Imtihan, "Implementasi Sms Gateway Pada Sistem Informasi Kesiswaan Sekolah Menengah Atas Negeri (Sman) 1 Praya Tengah Menggunakan Metode Extreme Programming (Xp)," J. Manaj. Inform. dan Sist. Inf., vol. 2, no. 2, p. 27, 2019, doi: 10.36595/misi.V2i2.101.

[9] R. Raco, Metode Penelitian Kualitatif. Jakarta: PT Grasindo, anggota IKAPI, 2010.

[10] I. Gunawan, Metode Penelitian Kualitatif. Jakarta: Bumi Aksara, 2013.

[11] Nugrahani F. Metode Penelitian Kualitatif. Surakarta: Universitas Bangun Veteran Nusantara.

[12] N. S. Enggarani, "Kualitas Pelayanan Publik didalam Perizinan di Pelayanan Terpadu Satu Pintu (PTSP) Kantor Badan Penanaman Modal dan Pelayanan Perizinan Terpadu (BPMP2T) Kabupaten Boyolali," Law Justice, vol. 1, no. 1, p. 16, 2016, doi: 10.23917/laj.v1i1.2702.

[13] S. Z. Friandi, T. A. H, N. Hikmah, F. B. A, and S. Fitria, "Penerapan Sistem Informasi Manajemen Perizinan Online (Simponi) Berbasis Web Dengan Memakai Ci Framework," JUMANJI (Jurnal Masy. Inform. Unjani), vol. 3, no. 02, pp. 76-90, 2019.

[14] A. Qashlim, "Web Aplikasi Dashboard untuk Evaluasi Human Computer Interaction dan Usability," Jtriste, vol. 1, no. 2, pp. 39-49, 2014. 